International Journal of Environment, Ecology,

Family and Urban Studies (IJEEFUS)

ISSN(P): 2250-0065; ISSN(E): 2321-0109

Vol. 11, Issue 2, Dec 2021, 1-10

(C) TJPRC Pvt. Ltd.

\title{
CHALLENGES ASSOCIATED WITH MEASURING QUALITY OF RESIDENTIAL SATISFACTION IN FEDERAL HOUSING ESTATES IN ABIA STATE, NIGERIA
}

\section{KENNETH CHIBUEZE EFFE \& EBIWARI WOKEKORO}

Department of Estate Management, Rivers State University, Port Harcourt, Nigeria

ABSTRACT
The study examined challenges involved in measuring the quality of residential satisfaction with Federal Housing Estates
in Abia State, Nigeria, A mixed method research approach was adopted for this study with a questionnaire and interview
conducted on the residents. A sample of 75 households was selected from 105 housing units within the two public housing
estates with purposive sampling technique employed. The sample represents $78.6 \%$ of the total public housing unit as
population. Findings showed that the attributes for measuring quality of public housing that influence the overall
residential satisfaction are quality of physical, environmental, economic, social/behavioral and timing features of housing
units. Furthermore, the study revealed that with RII of >0.60 the challenges associated with measuring the quality
(performance) of residential satisfaction are physical and space related issues, social/behavioral (security and privacy level
of the housing unit), quality of public water and proximity from house to fire services, building maintenance (dilapidated
drainage system with poor sewage system), public facilities and functional related (parking space and power supply) and
structural design and policy. The study concluded that measuring quality (performance) of public housing will reduce the
challenges faced with residential satisfaction at Federal Housing Estates in Abia State.
KEYWORDS: Challenges, Measurement, Quality, Public Housing \& Residential Satisfaction

Received: Apr 27, 2021; Accepted: May 17, 2021; Published: Jun 12, 2021; Paper Id.: IJEEFUSDEC20211

\section{INTRODUCTION}

Public housing estates across the world are often viewed as means of development and encouragement for the main purpose of improving the living conditions of residence. Be it developed or developing countries, public housing estates could be seen as the bedrock to measure any viable economy; to ensure all citizen own or have direct access to affordable houses. According to Salisu, Odulaja, Ogunseye, Fasina and Okumubi (2019), housing affects all facets of human life, particularly through the provision of shelter and other multiplier effects including socio-economic, cultural and political development. These increases productivity and standard of living, as well as alleviating poverty among inhabitants (Kolawole, 2015; Mohit and Nazyddah, 2011; Jiboye, 2010; Lee and Park, 2010).

It was expected that the provision of public housing estates should have met government prescribed standards of quality to measure end-users needs, expectation and aspirations. This has always been the goal of every public housing programme in Nigeria. Despite government laudable efforts in the past few decades, the UN-Habitat (2006) reported that public housing programmes have failed to achieve this goal in Nigeria. The type and quality of the public housing would have a significant impact on the health of the residents, particularly in the urban areas. The measurement of their quality has the ability to attract, retain and provide required dwellings for habitation that relies heavily on quality, attractiveness and eco-friendliness of building infrastructure and facilities as well as surrounding neighborhoods. However, measuring the quality of residential satisfaction according to Nkpite and 
Frank (2019) will enhance the improvement of building infrastructural facilities, and this provision is an enabler of economic growth, by ensuring new buildings have the right quality measures and types that are delivered at the right place for the right occupants.

Public housing estates are expected to provide residents with accessible, safe, beautiful and attractive accommodations in a sustainable manner. But it has become a subject of public discourse as it concerns the quality and quantity of its infrastructural facilities and design standards. This suggests that the challenges facing public housing estates have not been rightly addressed. In order to achieve public housing needs, the quality measurement of residential satisfaction being put in place will provide sustainable solutions to the quality and quantity of public housing estates.

Moreso, many researchers have concentrated their studies on preferences on housing condition, urban housing provision, residential satisfaction and neighborhood environmental quality, thus, there is an obvious paucity of empirical studies relating to the challenges associated with measuring the quality of residential satisfaction at Federal Housing Estates in Abia State. Based on the backdrops, this study investigates the challenges associated with measuring quality of resident's satisfaction with public housing estates in Abia State, Nigeria.

\subsection{Aim and Objectives of the Paper}

The aim of this study is to examine the challenges associated with quality measurement of residential satisfaction in Federal Housing Estates. Abia State, Nigeria. The specific objectives are to:

- Identity the attributing factors for measuring quality of residential satisfaction

- Identify the challenges faced with measuring the quality of residential satisfaction.

\section{LITERATURE REVIEW}

\subsection{Housing}

In general term housing which refers to a building that functions as a home, ranges from simple dwelling to complex fixed structure of wood, brick, concrete and other related materials containing bedrooms, bathrooms, kitchen, living room, dining room, water and plumbing system, power and electrical system including cross ventilation (Salisu et.al.,2019; Mohit and Nazyddah, 2011; Park and Lee, 2010). Housing reflected socio-cultural and economic values including historical evidence of civilization to a society (Mohit and Nazyddah, 2011). However the type and quality of housing have a significant impact on the health and wealth of the people, particularly people in urban areas (Salisu, et. al., 2011). Housing has the ability to attract, retain and provide required shelter for inhabitants (Kolawale, 2015), it relies heavily on quality, attractiveness and eco-friendliness of housing infrastructure and facilities as well as surrounding neighborhoods (Housing Corporation, 2008). The quality and improvement of housing infrastructural facilities according to Salisu, et. al., 2019), is undoubtedly, an enabler of economic growth, when new homes with the right quality and type are ensured and delivered in the right place for the right individuals.

\subsection{Public Housing}

According to Jiboye (2010), housing operates in three forms; public, private and social housing. From this expression of the three forms of housing, Olatubara and Fatoye (2006) defined public housing as a form that is provided and owned by government authority. Mohit and Nazyddah (2011), defined public housing as a building constructed for the purposes of providing affordable shelter or accommodation for the general public who are willing to pay a substantial amount either on 
installment or at once, depending on the criteria for allocation that varies within different contexts. Osman and Lemmer (2002) explained that public housing is to provide residents with accessible, safe, beautiful and attractive accommodation in a sustainable manner for human development and survival, since it is a basic requirement and major concern worldwide. However, it is true with the foregoing assertion according to Salisu et. al. (2019) housing affects the welfare, health and productivity of individuals and households.

\subsection{Public Housing Quality Measurement}

According to UN-Habitat (2006), public housing quality is a standard residential structure built in an environment designed for humans physical and mental health balance including the social wellbeing of the people. However, the right of residents to public housing is basically to provide security, privacy, neighborhood and social relations status, community facilities and services, access to employment and control over the environmental problems (Salisu, et al., 2019). Ibem, Adeboye and Alagbe (2015) stated that public housing in both developed and developing countries are developed and encouraged to be the main purpose of improving standards of residence, as well as ensuring that all citizens own or have direct access to decent, safe, and sanitary housing in a healthy environment with adequate infrastructural services at affordable cost, and with secure tenure. According to this goal, governments: federal, state and local levels in Nigeria have developed large-scale public housing for its citizen towards achieving the overall goal of meeting housing needs, satisfaction and sustainability of the increasing population (Nkpite and Frank, 2019).

\subsection{Public Housing Residential Satisfaction}

Public residential satisfaction according to Salisu, et al., (2019) is the degree to which the end-users of a dwelling unit feel that their building facilities help them achieve their goals. Housing satisfaction as defined is the concept of assigned prominent indicators used by researchers and analysts as an evaluation measure for private and public housing sectors' building performance of resident mobility and end-user perception of their residential environment and improvement in new project (Oliveira and Heineck 1999). Olatubara and Fatoye (2006) view public housing satisfaction as the measure of the degree to which building (quality) performance meets the end-user's expectation in terms of cost, benefit and needs.

It is seen that quality design of buildings and environmental requirements of the end-users are merely for accommodation purposes which is without infrastructural facilities commonly believed as public housing provision in the urban areas (Nkpite and Ohochukwu 2020). In view of this, Fatoye and Odusam (2009) suggested that public housing sector must explore and understand end-user's needs and expectation as well as the extent to which such needs and expectations are met through regular measurement to improve the quality of housing it produces. Teck-Hong (2011) shares a similar view by noting that one possible way to meet end-users' housing needs is to examine the problems which account for residents' satisfaction or dissatisfaction with their building conditions and environment. These views no doubt underscore the need for studies on quality measurement of residential satisfaction in the quest to provide buildings that meet the daily needs, expectations and preferences of the end-users. Galster (1987) as cited in Ibem and Adawo (2013) noted that people consciously construct a reference quality or quality that is an ideal standard of the different aspects of their residential quality based on their needs, experience and aspirations. As a result, they tend to measure the quality of the building conditions based on the ideal standards which they have already created a mental picture of and aspire to have. According to Ibem and Aduwo (2013), if the current building condition is perceived to be in close congruence with or superior to the reference condition, they tend to express satisfaction and vice versa. This means that the actual aspiration between what the end-users want and aspire to have and what they currently have in terms of their building conditions is seen as a quality measurement 
of residential satisfaction. The foregoing suggests that quality measurement of building conditions depends largely on the meaning they attach to their building, standard of reference condition to which they compare it with and their housing needs, preferences, expectations and aspirations.

\subsection{Challenges Associated with Measuring Quality of Residential Satisfaction}

In spite of the efforts put in place by the Federal Government of Nigeria according to Salisu, et. al. (2019) to provide sustainable solutions to the quality and quantity of public housing has been the challenges confronting citizens of this country. The Public housing within urban areas are also still faced with several challenges, which includes but not limited to poor room and unit space, poor toilet facilities, poor air quality and ventilation issue, noise and environmental pollution, poor proximity of house to the market, police station, fire services and workplace, absence of quality public water, unstable power and electricity, poor parking lot, insecurity and high crime rate, dilapidated structures with sudden collapse cases, poor house maintenance with uniformly house painting, abandoned and dilapidated drainage system and poor regulatory and policy implementation (Salisu et, al., 2019).

However, the bulk of these housing inadequacies are borne by the less privileged in society (Ibem and Aduwo, 2013). This suggests that Nigeria is yet to get it right in meeting the public housing needs and satisfaction with standardized facilities as means of quality measurement of residential satisfaction. According to Salusu, et. al. (2019) these challenges of quality measurement among others hinders the residential satisfaction of public housing estates in Nigeria the unsatisfactory level of end-users' of these public facilities, has equally contributed to the alarming urban stress, poverty and poor living standard, high crime rate, traffic congestion, and slum development within urban areas in Nigeria (Nkpite and Ohochuku, 2020). However, these challenges from reviewed literature can be summarized under six attributing factors; according to Salisu, et, al., (2019); Inah, Yaro, Agbor and Ukene (2014); Mohit and Azim (2012) to be physical environmental, economical, public facilities/functional, social/behavioural and timing.

It is evident from the foregoing review of literature that varying assortment of factors within and outside the public housing estates domain and personal attributes of the residents can pose challenges to quality measurement of residential satisfaction across Federal Housing Estates at Abia State. However, of residential satisfaction across culture Federal Housing Estates at Abia State faced in measuring quality of residential satisfaction. This study was an attempt to bridge this gap. Also from existing studies, it was observed that many researchers have studied factors relating public housing facilities and environmental quality with residents satisfaction based on the factors that are relevant to the context and purpose of their research (see Fang, 2006; Mohit and Nazyddah, 2011; Tech-Hong, 2011; Salisu, et al., 2019; Ukoha and Beamish, 1996). These studies include factors such as housing unit characteristic, dwelling unit support services, neighborhood environment, management of housing estates, housing acquisition process, socio-economic and demographic characteristics of the residents, considered to be relevant to the housing market in the study area. Furthermore, Choudhury (2005); Ibem and Amole (2012) studies noted that residential satisfaction is a measure of the end-users perception of the quality of their residential environment in meeting their needs, expectations and aspirations, but fails to look at the challenges. Therefore, based on the backdrops, a need arises to examine the challenges in measuring the quality of residential satisfaction at Federal Housing Estate in Abia State, Nigeria in order to provide a better understanding to building satisfaction culture and its application to overcome the challenges to public housing programs. 


\section{RESEARCH METHODOLOGY}

The research design utilized in this study was a cross sectional survey design that involves a number of public houses built across two (2) locations in Abia State by the Federal Government of Nigeria. The study adopted mixed method approach; that is both quantitative and qualitative data were sourced and used. The targeted population comprises mainly residents of buildings in Federal Housing Estates; Ogbo-Hill Aba and Umuahia in Abia State who have resided there for more than 5 years. A sample of 75 households was selected from 105 housing units within the two public housing estates of Abia State. The sample represents $78.6 \%$ of the total public housing units. The primary data for this study were collected through selfadministered questionnaires and face-to-face interview. In Federal Housing Estate, Ogbo-Hill Aba 84\% of the questionnaires were retrieved, while $75.6 \%$ were retrieved from Federal Housing Estate Umuahia. The questionnaires used a 5 point Likert scale to assess the challenges associated with measuring the quality of residential satisfaction; $1=$ strongly disagree, $2=$ disagree, $3=$ undecided, $4=$ Agreed, and $5=$ strongly agree. The study also used observation to identify the conditions of the provided facilities in public housing estates. Descriptive statistical tools such as percentage and mean score as well as content analysis were used to analyze collected data. The overall challenges affecting the measurement quality of residential satisfaction was analyzed based on a mean score of 3.00 as positive indication of satisfaction, and value below 3.00 indicating dissatisfaction.

\section{RESULTS DISCUSSION AND DATA ANALYSIS}

This section of the study presents the challenges affecting quality of measurement with residential satisfaction in public housing estates. It will outline the challenges as well as determine the level of residential satisfaction with the attributing factors of measuring quality. The analysis utilizes simple percentage and relative importance index (RII) to achieve these particular objectives.

\subsection{Attributing Components for Measuring Quality of Residential Satisfaction}

Table 1 presents the components for measuring quality of residential satisfaction with attributing factors of physical, environmental, economic, public facilities/ functional, social/ behavioral and timing. From an in-depth interview with respondents. The results are presented below.

\section{Physical Attributes}

Physical components of public housing estates are important aspects for measuring quality of residential satisfaction of dwelling unit. It shows that physical attribute is the degree of resident's attachment to the standard of the building as it enhances structural durability of the building. Hence, residential satisfaction with physical attributes of public housing measures the quality which the respondents were either satisfied or dissatisfied in the size of premises, size of rooms, electrical fixtures, number of rooms, availability of toilet and bathroom, operation of doors, quality of building materials, storage space and building heights as physical components. Hence, it is worthy to note that most of the physical components for measuring quality of residential satisfaction of public housing estates as indicated by majority of residents were not satisfied with physical attributes of Federal Housing Estates in Abia State.

\section{Environmental Attributes}

In the bid to measure the quality of residential satisfaction derived from environmental attributes of public housing estates, questions of environmental concerns were asked and the responses are based on either satisfaction or dissatisfaction with the 
degree of; free cross ventilation, control level of air, noise and water pollution, availability of good road, drainage system and waste disposal system. Noteworthy, high level of residential satisfaction with respect to cross ventilation for instance can be attributed to the fact that government agencies that build public estates deployed professionals who are aware of planning standards and regulations appropriate to such projects. And also, there are legislations that prohibit air, noise and water pollutions as observed waste management were not monitored by the government and gone around for routine collection. It implies that environmental attribute for measuring quality of residential satisfaction are the bases to determine the quality (performance) of public housing estates.

\section{Economic Attributes}

Measuring the quality of residential satisfaction with economic attributes are with the extent of socio-economic relation among neighbors; proximity to school for children; proximity to market; proximity to workplace; cost.of building maintenance. Nevertheless, as observed, public housing estates are operated on owner-occupier arrangement and the challenges of maintenance lie with the government and the owner where the residents can be either satisfied or dissatisfied with building maintenance as economic components for measuring quality of residential satisfaction with public housing units. Quality of measurement with maintenance components is an indication of neglecting and managing the public housing estates by appropriate authorities. However, there are limits on government involvement in terms of maintenance, as government spending have to be appropriated before execution of projects. It implies that the residents would be compelled to carry out necessary maintenance if government intervention is not forthcoming and this would in turn impact on the resident's income as to cater for immediate family's need.

\section{Social or Behavioral Attributes}

Residential satisfaction with social/ behavioral attributes in measuring of quality of public housing estates deals with level of individuals privacy within the house; proximity to place of worship; building setbacks; security level of building; physical appearance; proximity of house to police station; proximity of house to hospital; proximity of house to fire station. The social or behavioral attributes for measuring quality of public housing may be connected to the increasing land use conversion of residential properties to places of worship, education and health facility centers that yielded higher uses since these facilities are absent in the estates as to derive satisfaction. From interview, public housing physical appearance has been left to individual occupier to execute their desired renovation plan, which ought to be a collective effort of government and occupier in order to achieve a pleasant appearance. However, measuring the quality of satisfaction or dissatisfaction with proximity to police and fire stations seems not far-fetched as these are higher-order facilities serving more than a single neighborhood, but are absent in this study area.

\section{Public Facilities/Functional Attributes}

Measurement of the quality of the level of residential satisfaction derived from public facilities/functional attributes in public housing estates represents the satisfaction or dissatisfaction with the position of different rooms, size of parking space and functionality in design. From observation, public housing estates have sufficient space for parking, hence supporting satisfaction level among residents interviewed. Also, measurement in quality with dissatisfaction by occupants may arise concerning rooms positioning and functionality in design been linked to lack of end-user's involvement in the housing design from inception of the projects. 
in Federal Housing Estates in Abia State, Nigeria

\section{Timing Attributes}

Residential satisfaction with timing attributes measured the quality with frequency of building maintenance, since the residents of housing units believe engaging in major building maintenance require huge capital and specific building materials which could have been the responsibility of the occupants and the government; and where the occupants pay rent and other government charges for used facilities and services. It implies that the apathy towards maintenance has to reflect in quality measurement of residential satisfaction as it impacted negatively on the appearance of the public housing estates in the area where the paint on the walls is faded. The level ofresidential satisfaction with attributing components of public housing quality of measurement varies among residents which are based on physical, environmental, economical, public facilities/functional, social/behavioral and timing features on housing satisfaction and performance components. However, the overall contribution of the six (6) components for measuring the quality of public housing influence the overall residential satisfaction. By implication, the more the quality of physical, environmental, economic, social/behavioral and timing features of housing units are measured, the higher the level of residential satisfaction with public housing estates.

Table 1: Attributes and Components for Measuring Quality Residential Satisfaction

\begin{tabular}{|l|l|}
\hline \multicolumn{1}{|c|}{ Attributes } & \multicolumn{1}{c|}{ Components for Measuring Quality } \\
\hline Physical & $\begin{array}{l}\text { Premises size; rooms size; electrical fixtures; number of rooms; availability of toilet and } \\
\text { bathroom; operation of doors; quality of building materials; storage space; building heights. }\end{array}$ \\
\hline Environmental & $\begin{array}{l}\text { Free ventilation; air, noise and water pollution; availability of good road; drainage system; } \\
\text { waste disposal system. }\end{array}$ \\
\hline Economical & $\begin{array}{l}\text { Extent of socio-economic relation among neighbors; proximity to school for children; } \\
\text { proximity to market; proximity to workplace; building maintenance. }\end{array}$ \\
\hline $\begin{array}{l}\text { Public } \\
\text { Facilities/Functional }\end{array}$ & Position of different rooms; parking space; functionality in design. \\
\hline Social/Behavioral & $\begin{array}{l}\text { Level of individuals privacy within the house; proximity to place of worship; building } \\
\text { setbacks; security level of building; physical appearance; proximity of house to police station; } \\
\text { proximity of house to hospital; proximity of house to fire station. }\end{array}$ \\
\hline Timing & Frequency of building maintenance \\
\hline Source: adapted from Mohit and Azim (2012) and Modified by Authors. \\
\hline
\end{tabular}

\subsection{Challenges Associated with Measuring the Quality of Residential Satisfaction}

The challenges affecting measuring the quality of residential satisfaction in public housing estates were identified in Table 2. Table 2 indicates the relative importance index (RII) of physical and space related issues and social/behavioral challenges (security and privacy level of the housing unit) with measuring the quality of satisfaction of residents in public housing estates were ranked with RII of $0.63\left(1^{\text {st }}\right)$ respectively, quality of public water and proximity of house to fire services with RII of $0.62\left(2^{\text {nd }}\right)$, while building maintenance challenges (dilapidated drainage system with poor sewage system) with RII of $0.61\left(3^{\text {rd }}\right)$ and public facilities and functional related challenges (parking space and power supply) and structural design and policy challenges with RII of $0.60\left(4^{\text {th }}\right)$ as major challenges affecting measuring the quality of residential satisfaction with public housing estate. Hence, it is important to note that majority of the residents agreed to most of the identified challenges in measuring quality as affecting residential satisfaction with public housing units within the study area. The study revealed that the challenges associated with measuring the quality (performance) of residential satisfaction are physical and space related issues, social/behavioral (security and privacy level of the housing unit), quality of public water and proximity from house to fire services, building maintenance (dilapidated drainage system with poor sewage system), public facilities and functional related (parking space and power supply) and structural design and policy. The level of residential satisfaction with public housing units and condition of space allocation, quality of services, p public infrastructural facilities and social 
environment of Federal Housing Estates in Abia State are lower than expected. That is housing units and conditions being unsatisfactory pose challenges to the measurement of quality in residential satisfaction.

Table 2: Challenges Associated with Measuring Quality of Residential Satisfaction

\begin{tabular}{|c|c|c|c|c|c|c|c|c|c|}
\hline \multirow{2}{*}{ Challenges Attributes } & \multicolumn{5}{|c|}{ Weigh: $N=75$} & \multirow{2}{*}{$\Sigma f \boldsymbol{x}$} & \multirow{2}{*}{$\frac{\Sigma f x}{\Sigma f}$} & \multirow[b]{2}{*}{ RII } & \multirow{2}{*}{ Rank } \\
\hline & 5 & 4 & 3 & 2 & 1 & & & & \\
\hline $\begin{array}{l}\text { Physical and space related } \\
\text { challenges }\end{array}$ & 13 & 12 & 10 & 10 & 10 & 173 & 3.14 & 0.63 & $1^{\mathrm{st}}$ \\
\hline $\begin{array}{l}\text { Environmental challenges (air and } \\
\text { noise quality; pollution and } \\
\text { proximity of house to market). }\end{array}$ & 11 & 12 & 10 & 12 & 10 & 107 & 3.03 & 0.61 & $3^{\text {rd }}$ \\
\hline $\begin{array}{l}\text { Quality of public water and } \\
\text { proximity from house to fire } \\
\text { services }\end{array}$ & 7 & 16 & 14 & 9 & 9 & 168 & 3.05 & 0.62 & $2^{\text {nd }}$ \\
\hline $\begin{array}{l}\text { Public Facilities and Functional } \\
\text { related challenges (parking space } \\
\text { and power supply). }\end{array}$ & 11 & 11 & 11 & 11 & 11 & 165 & 3.00 & 0.60 & $4^{\text {th }}$ \\
\hline $\begin{array}{l}\text { Social/Behavioral challenges } \\
\text { (security and privacy level of the } \\
\text { housing unit). }\end{array}$ & 14 & 10 & 11 & 11 & 9 & 174 & 3.16 & 0.63 & $1^{\mathrm{st}}$ \\
\hline $\begin{array}{l}\text { Building maintenance challenges } \\
\text { (dilapidated drainage system with } \\
\text { poor sewage system). }\end{array}$ & 12 & 11 & 12 & 10 & 10 & 170 & 3.09 & 0.61 & $3^{\text {rd }}$ \\
\hline $\begin{array}{l}\text { Structural design and policy } \\
\text { challenges }\end{array}$ & 11 & 10 & 14 & 10 & 9 & 166 & 3.02 & 0.60 & $4^{\text {th }}$ \\
\hline \multicolumn{10}{|c|}{ Legend: $1=$ Strongly disagree, $2=$ Disagree, $3=$ Undecided, $4=$ Agree and $5=$ Strongly Agree. } \\
\hline & & & & & & & & & \\
\hline
\end{tabular}

\subsection{CONCLUSIONS AND RECOMMENDATIONS}

The study examined the challenging factors attributed to measuring quality of residential satisfaction with Federal Housing Estates in Abia State, Nigeria with view to identify attributing components and challenges influencing residential satisfaction measurement quality. The study found that physical, environmental, economical, public facilities/functional, social/behavioral and timing features are bases for measuring quality of residential satisfaction. This study revealed that majority of residents of the public estates were absolutely dissatisfied with space allocation, quality of services and public facilities within the estates. The study also found that the challenges associated with measuring quality of residential satisfaction in public housing estates are physical and space related issues, social/behavioral (security and privacy level of the housing unit), quality of public water and proximity of house to fire services, building maintenance (dilapidated drainage system with poor sewage system), public facilities and functional related (parking space and power supply) and structural design and policy. The study also established that poor unit spacing and related issues, poor structural design and maintenance policy, absence of quality water and fire service station, unstable power supply and poor parking lots, insecurity and high crime rate, and poor drainage and sewage system are the challenges faced in quantifying residential satisfaction at public housing estates. However, findings emphasize that mere provision of public housing estates does not guarantee successful housing development, but to meet actual needs and preferences for residential satisfaction with lower maintenance cost and structural standard to determine quality measures. The study concluded that measuring quality (performance) of public housing will reduce the challenges faced with residential satisfaction at Federal Housing Estates in Abia State.

\section{REFERENCES}


1. Adewale, B.A., Ibem, E.O., Amole, B. and Adeboye, A.B. (2018). Assessment of Residential Satisfaction in the Core Area of Ibadan Metropolis, Nigeria. Journal of Human Behavior in Social Environment, 29 (2), 206-233.

2. Amole, D. and Ibem, E.O. (2012). Public Housing Programme and User's Satisfaction in Ondo State, Nigeria PhD Thesis Department of Architecture, Faculty of Environmental Sciences, University of Teknologi, Malaysia.

3. Amusan Lekan, Akintaro Hezekiah, Osawaru Faith, Makinde Adebisi, Tunji-Olayeni Patience \& Akomolafe Maryam, “Information on State of Challenges of Waste Management System in Nigeria Urban Housing System”, International Journal of Mechanical and Production Engineering Research and Development (IJMPERD) ISSN (P): 2249-6890; ISSN (E): 2249-8001 Vol. 8, Issue 2,pp, 75-86

4. Choudhury, I. (2005). A Conceptual Model of Resident Satisfaction with reference to Neighborhood Composition. Paper for XXXIII IAHS World Congress on Housing; Transforming Housing Environments through Design, September 27-30, Pretoria, South Africa.

5. Amusan, M. Lekan, Clinton Aigbavboa Aremu J. Adekunle \& Adediran C. Ayodele, "Developing Sustainable Urban-Rural Housing System: Formulating Implementation Framework sing Block Diagram And Heuristic Algorithm System "International Journal of Mechanical and Production Engineering Research and Development (IJMPERD) ISSN (P): 2249-6890; ISSN (E): 2249-8001 Vol. 10, Issue 3,pp, 3429-3438

6. Fong, A. Y. (2006). Housing Satisfaction: Department of Economics and Business Administration Building, Room 123 University of Albany State University of New York Albany, NY, 12222.

7. Galster, G.C. (1987). Identifying the Correlates of Dwelling Satisfaction. Environment and Behavior, 19 (5).

8. Iwan Satibi \& Erick Muhammad Henrizal, "Models of Central and Regional Government Policy in the Procurement of Housing for Low-Income Communities in Indonesia”, International Journal of Humanities and Social Sciences (IJHSS), Vol. 8, Issue 5,pp; $73-78$

9. Housing Corporation (2008). Good Practice Note 16: working with Local Authorities. London: The Housing Corporation.

10. Ibem,E.O., Opoko,P.A. and Aduwo, E.B. (2013). Satisfaction with Neighborhood Environment in Public Housing: Evidence from Ogun State, Nigeria. Social Indicators Research, 130, 733-757.

11. Salma Begum, “"Space Vs Place”_Focusing On the Plaza in Front of Building No 9 in Peterbos Social Housing, Brussels, Belgium,',International Journal of Civil Engineering ( IJCE), Vol. 7, Issue 1, pp; 1-8

12. Inah, S.A., Yaro, M.A., Agbor, E.A.and Ukene, D. (2014). Residential Housing Satisfaction of the Urban Poor in Calabar Metropolis, Nigeria. Journal of Architecture Research, 4 (1A): 1-8.

13. Jiboye, A. D. (2009). Evaluating Tenant's satisfaction with Public Housing in Lagos, Nigeria. Town Planning and Architecture, 33(4), 239-247

14. Kolawole, Y. (2015). Housing as a Tool for Economic Development. Vanguard Newspapers. Retrieved from https://www.vanguardngr.com/2015/11/housing-as-tool-for-economic-development/

15. Lee, E. and Park, N. (2010). Housing Satisfaction and Quality of Life among Temporary Residents in the United States. Housing and Society, 37 (1), 43-67.

16. Mohbit, M. A. and Azim, M. (2012). Assessment of Residential satisfaction with Public Housing in Hulhumale, Maldiras Procedia; Social and Behavioral Sciences, 50, 756-770. 
17. Mohit, M. A. and Nazyddah, N. (2011). Social Housing programme of Selangor Zakar Board and Housing Satisfaction, Journal of Housing and the Built Environment 26(1), 123-142.

18. Mohit, M. A. Ibrahim, M. and Rashid, Y. R. (2010). Assessment of Residential satisfaction in Newly Designed Public Low-cost Housing in Kuala Lumpur, Malaysia. Habital International, 34(1), 18-27.

19. Nkpite, B. S. and Frank, O.L. (2019). Potential Benefits for Adopting Post Occupancy Evaluation (POE) as Maintainability Tool for Nigerian Public School Buildings. International Journal of Science, Arts and Commerce, 4 (1), 79-89.

20. Nkpite, B. S. and Frank, O.L. (2019). Evaluating the Influence of School Based Management on Maintenance Management of Public School Buildings. International Journal of Latest Engineering and Management Research (IJLEMR), 3(2), 2455-2465.

21. Nkpite, B. S. and Ohochuku, C.P. (2020). Challenges of Managing Quality Assurance Activities as Panacea for the Transformation of Practicing Facility Management during Pandemic Occurrence. International Journal of Advanced academic studies, 2 (4); 211-215.

22. Olatubara, C.O. and Fatoye, E.O. (2006). Residential Satisfaction in Public Estates in Lagos State, Nigeria. Journal of Nigerian Institute of Town Planners, 19 (1); 103-124.

23. Oliveira, M.C.G. and Heineck, L.F.M. (1999). An Investigation into the Determinants of Built Environment Customer Satisfaction: A Focus for Research and Practices. Cape Town South Africa, 5-10.

24. Osman, A. and Lemmer, C. (2002). Architecture and Housing: Changing Perceptions in the New South Africa. The Case of Pretoria University. Proceedings of XXX IAHS World Congress on Housing, Coimbra, September.

25. Salisu, U.O., Odulaja, A.O., Ogunseye, N.O., Fasina, S.O. and Okunubi, S.A. (2019). Residents Satisfaction with Public Housing in Lagos, Nigeria. Ghana Journal of Geography, 11(1), 15-25.

26. Teck-Hong, t. (2011). Housing Satisfaction in Medium-and-High-Cost Housing: The Case of Greater Kuala Lumur, Malaysia. HABITAT International, 35(3), 1-9.

27. Ukoha, O.M. and Beamish, J.O. (1996). Assessment of Residents' Satisfaction with Public Housing in Abuja, Nigeria. HABITAT International, 21 (4); 445-460.

28. UN-Habitat (2006). National Experiences with Shelter Delivery for the Poorest Groups, Nairobi: UN-Habitat. 